\title{
Pelatihan Berpikir Positif untuk Menurunkan Kecemasan Menghadapi Masa Bebas pada Anak di Lembaga Pembinaan Khusus Anak Kutoarjo
}

\author{
Lainatussyifa Zulni ${ }^{1} \mathcal{E}$ Koentjoro $^{2}$ \\ Fakultas Psikologi Universitas Gadjah Mada
}

\begin{abstract}
Anxiety against liberation is a feeling of fear and concern, felt by someone who underwent a period of custody and will undergo a period of free. This anxiety will make a person feeling ostracized, denied his presence, even humiliated or insulted. One of the factor that considered influential in reduction of anxiety against liberation is positive thinking. The purpose of this study was to develops positive thinking training as an alternative to solving anxiety problems facing the anxiety against liberation in children at prison special for children. This experiment conducted with untreated control group design with pretest and posttest design. Quantitative data analysis is done through a mixed ANOVA statistical test to determine the effects of positive thinking training to experimental group between before and after training. The results of this study is positive thinking training can reduce anxiety against liberation on children at prison.
\end{abstract}

Keywords: anxiety against liberation; positive thinking training.

Abstrak. Kecemasan menghadapi masa bebas merupakan suatu perasaan ketakutan dan kekhawatiran, yang dirasakan oleh seseorang yang tengah menjalani masa tahanan dan akan menjalani masa bebas. Kecemasan ini membuat seseorang merasa akan diasingkan, ditolak keberadaanya, bahkan dipermalukan atau dihina. Salah satu faktor yang dianggap berpengaruh dalam menurunkan kecemasan menghadapi masa bebas adalah berpikir positif. Tujuan dari penelitian ini yaitu untuk mengembangkan Pelatihan Berpikir Positif sebagai alternatif pemecahan masalah kecemasan menghadapi masa bebas pada anak di Lembaga Pembinaan Khusus Anak. Desain yang digunakan dalam penelitian ini adalah untreated control group design with pretest and posttest. Analisis data kuantitatif dilakukan melalui uji statistik mixed ANOVA untuk mengetahui efek pelatihan berpikir positif terhadap kelompok eksperimen sebelum dan sesudah pelatihan. Hasil penelitian ini adalah pelatihan berpikir positif dapat menurunkan kecemasan menghadapi masa bebas pada anak di LPKA.

Kata kunci: kecemasan menghadapi masa bebas; pelatihan berpikir positif.

\footnotetext{
${ }^{1}$ Korespondensi mengenai isi artikel ini dapat dilakukan melalui: syifazulni@gmail.com

2 Atau melalui koentjoro@ugm.ac.id
} 
Status yang disandang oleh anak berkonflik dengan hukum, membuat mereka berpikir akan masa bebas yang kelak dihadapi. Ada kekhawatiran tentang bagaimana anak akan menjalani kehidupan setelah bebas. Hardiani (2012) dalam penelitiannya menemukan, bahwa terdapat kekhawatiran pada diri anak di LPKA yaitu kekhawatiran atas ketidakpedulian dari keluarga dan perasaan malu serta akan ditolak oleh masyarakat. Pada anak juga ditemukan adanya ketakutan penolakan sosial, perlakuan berbeda di lingkungan keluarga, dan penerimaan dari masyarakat yang mengucilkan (Febrilinda, 2016). Kecemasan yang kemudian menimbulkan pemikiran dan perasaan subjektif seperti ketakutan, kekhawatiran, dan perasaan tidak mampu untuk menghadapi masa bebas yang bersifat negatif. Jika anak mengalami kecemasan yang berlebihan, maka akan memengaruhi kehidupan sehari-hari anak yang akan berdampak pada rendahnya kepercayaan diri, kemampuan mengatasi permasalahan atau strategi koping, penilaian terhadap diri yang cenderung negatif, serta persepsi kondisi fisik yang buruk (Lewis, 1997).

Faktor yang dianggap memberikan pengaruh pada kecemasan menghadapi masa bebas pada anak di LPKA adalah adanya pola pikir negatif terhadap diri, lingkungan, dan masalah yang dihadapi. Munculnya pikiran negatif kemudian berkaitan dengan bagaimana proses berpikir itu sendiri. Pikiran-pikiran negatif seringkali muncul sehingga menyebabkan seseorang merasa takut, cemas, stress, hingga depresi. Sumber permasalahan berupa pola pikir yang negatif terhadap diri, lingkungan dan masalah yang dihadapi, pada dasarnya merupakan sebuah ancaman terhadap keberlangsungan hidup setiap individu sehingga setiap individu perlu untuk mengantisipasi kondisi tersebut (Stallard, 2005).

Salah satu upaya guna mengatasi kecemasan adalah dengan pemberian intervensi. Berpikir positif menjadi bagian dari intervensi kognitif. Kecemasan dapat muncul karena adanya cara berpikir negatif, sehingga dengan mampu mengubah pola pikir yang negatif menjadi positif, akan meminimalisasi kecemasan yang dirasakan. Peale (1996) menjelaskan bahwa perjuangan utama dalam mencapai kedamaian mental adalah dengan mengubah sikap pikiran. Menurutnya, berpikir positif adalah aplikasi langsung yang praktis dari teknik spiritual untuk mengatasi kekalahan dan meningkatkan kepercayaan kemudian dapat mencapai perkembangan hasil yang positif. Berpikir positif akan melihat setiap kesulitan dengan cara yang gamblang, tidak terpengaruh, dan tidak mudah putus asa dengan adanya berbagai tantangan maupun hambatan yang dihadapi. Seligman (2006) juga menyebutkan bahwa dengan mengubah cara pandang atau cara berpikir yang negatif menjadi positif, maka individu yang pada awalnya stres akan berkurang gejala-gejala stresnya. Berpikir positif cenderung akan menafsirkan setiap permasalahan sebagai hal yang terjadi hanya sementara dan terkendali.

Berdasarkan penjelasan di atas, maka peneliti menentukan rumusan permasalahan yang hendak dijawab dalam penelitian ini, yakni apakah pelatihan berpikir positif efektif untuk menurunkan kecemasan menghadapi masa bebas pada anak di LPKA Kutoarjo. Penelitian bertujuan untuk mendapatkan alternatif pemecahan masalah kecemasan menghadapi masa bebas pada anak di LPKA melalui pelatihan berpikir positif. Manfaat dari penelitian secara teoritis 
adalah menambah perkembangan kajian ilmu pengetahuan dalam bidang Psikologi terutama Psikologi Klinis dan memperkaya referensi pelaksanaan desain eksperimen tentang intervensi kecemasan. Manfaat dari penelitian secara praktis adalah menghasilkan intervensi yang secara efektif dapat menurunkan kecemasan menghadapi masa bebas pada anak di Lembaga Pembinaan Khusus Anak dengan memberikan pelatihan berpikir positif. Hasil penelitian diharapkan dapat digunakan sebagai informasi yang bermanfaat bagi peneliti selanjutnya, praktisi psikologi, dan lembaga pembinaan khusus anak.

\section{Kecemasan}

Kecemasan berorientasi pada masa depan yang mengacu pada keadaan tertentu di mana individu memiliki kekhawatiran, ketegangan dan kegelisahan yang tidak terkendali tentang kemungkinan suatu hal buruk yang akan terjadi (Halgin, 2007). Hal yang tidak jauh berbeda dijelaskan oleh Zeidner dan Matthew (2010), yang menyatakan kecemasan mengacu pada kondisi psikologis di mana seseorang akan merasa khawatir, tegang dan gelisah terhadap situasi yang ambigu. Kecemasan adalah perasaan kegelisahan yang berawal dari adanya ketakutan terhadap sesuatu yang akan dihadapi dan bersifat individual (Chaplin, 2011). Spielberger (1972) membedakan kecemasan antara state anxiety dan trait anxiety. State anxiety bersifat sementara, di mana kecemasan merupakan kondisi emosional yang dialami individu dikarenakan adanya ketegangan dan kekhawatiran yang menghasilkan aktivitas sistem saraf otonom pada suatu keadaan tertentu. Sementara itu trait anxiety lebih mengarahkan pada kestabilan perbedaan kepribadian dalam kecenderungan untuk merasa cemas. Trait anxiety tidak langsung telihat pada tingkah laku individu, tetapi dapat di lihat dari frekuensi states anxiety individu. Dalam kaitan dengan masalah yang diangkat dalam penelitian ini, peneliti akan memfokuskan pada kecemasan sebagai reaksi individu pada suatu keadaan tertentu (state anxiety) yaitu menghadapi situasi atau keadaan yang tidak pasti ketika menghadapi masa bebas dan kembali ke masyarakat pada anak di Lembaga Pembinaan Khusus Anak.

\section{Berpikir positif}

Berpikir positif adalah suatu cara berpikir yang lebih menekankan dan memfokuskan pada sudut pandang dan emosi yang positif, baik terhadap diri sendiri, orang lain, maupun situasi yang dihadapi (Elfiky, 2009). Caprara \& Steca (2006) menjelaskan bahwa berpikir positif merupakan suatu cara untuk melihat realitas atau kejadian yang dialami secara positif. Berpikir positif juga merupakan sebuah strategi yang merefleksikan usaha yang dilakukan oleh seseorang untuk menyesuaikan diri dengan lingkungan yang dinilai penuh tekanan (Wadsworth, Gudmundsen, Raviv, Ahlkvist, Mclntosh, Kline, Rea \& Burwell, 2004). Berpikir positif merupakan sebuah cara berpikir yang optimis baik terhadap diri sendiri maupun lingkungan. Seligman (2006) menjelaskan bahwa seseorang yang berpikir positif, cenderung untuk menafsirkan permasalahan yang mereka hadapi sebagai hal yang hanya terjadi sementara, dapat dikendalikan, dan khusus hanya pada satu situasi. Sebaliknya, seseorang yang berpikir negatif memandang permasalahan yang dihadapi akan berlangsung selamanya dan tidak dapat dikendalikan. 


\section{Metode}

Penelitian yang berorientasi pemecahan masalah ini bertujuan untuk menguji secara empiris efektifitas pelatihan berpikir positif dalam menurunkan kecemasan menghadapi masa bebas pada anak di Lembaga Pembinaan Khusus Anak Kutoarjo. Subjek penelitian terdiri dari 12 orang anak berkonflik dengan hukum yang berada di Lembaga Pembinaan Khusus Anak (LPKA) Kutoarjo, berjenis kelamin laki-laki, sudah menjalani masa binaan minimal 1 tahun, dan masuk dalam kategori tindak pidana kejahatan sedang hingga berat. Penelitian ini merupakan penelitian action research. Dalam penelitian action research, terdapat empat tahap yang harus dilalui (Mertler \& Charles, 2005 dalam Mertler, 2006), yaitu perencanaan (planning); mencari permasalahan, mencari dasar teori yang sesuai dengan permasalahan, dan mengembangkan rencana penelitian, pelaksanaan (action); meliputi pelaksanaan intervensi, pengambilan dan analisis data, pengembangan (developing); mengembangkan rencana intervensi selanjutnya, dan refleksi (reflection); meliputi refleksi dari proses penelitian dan penyampaian hasil penelitian.

Metode kuasi eksperimen dilakukan untuk menguji pengaruh pelatihan berpikir positif terhadap penurunan kecemasan menghadapi masa bebas pada anak di Lembaga Pembinaan Khusus Anak. Desain kuasi eksperimen yang digunakan dalam penelitian ini adalah the untreated control group design with pretest and posttest (Cook \& Campbell, 1979), yaitu bagian dari desain eksperimen dua kelompok (between subject design) yang dirancang dengan membagi subjek secara random ke dalam kelompok eksperimen dan kelompok kontrol. Pengujian data dilakukan dengan menggunakan analisis mixed anova (Shadish et al., 2002). Teknik ini dipilih, karena di dalamnya memadukan dua sub analisis yaitu within subject test dan between subject test. Within subject test adalah pengujian perbedaan skor dalam satu kelompok (pretest dan posttest), sedangkan between subject test adalah pengujian perbedaan skor antar kelompok, yakni kelompok eksperimen dan kelompok kontrol.

\section{Hasil}

\section{Hasil cek manipulasi eksperimen}

Tes pengetahuan berpikir positif merupakan cek manipulasi yang digunakan dalam penelitian ini. Tes pengetahuan digunakan untuk memastikan apakah materi yang disampaikan dalam pelatihan sudah dipahami oleh peserta. Tes ini diberikan kepada subjek penelitian pada kelompok eksperimen sebelum dan setelah pelatihan diberikan.

Sebelum pelatihan, rerata skor pengetahuan kebersyukuran adalah 9,33 dan setelah seluruh proses rangkaian pelatihan selesai, maka rerata naik menjadi 12,17. Hasil uji-t sebesar -2,041 dan signifikansi sebesar $0,041 \quad(\mathrm{p}<0.05)$. Hal ini menunjukkan bahwa adanya peningkatan yang signifikan, terhadap

Tabel 1.

Hasil uji-t cek manipulasi pengetahuan berpikir positif kelompok eksperimen

\begin{tabular}{c|c|c|c|c|c}
\hline \multicolumn{5}{c}{ Pengetahuan Berpikir Positif Kelompok Eksperimen } \\
\hline \multirow{2}{*}{ Rerata } & $\begin{array}{c}\text { Deviasi } \\
\text { Standar }\end{array}$ & Rerata & $\begin{array}{l}\text { Deviasi } \\
\text { Standar }\end{array}$ & $\mathrm{t}$ & Sig \\
\hline 9.33 & 1.033 & 12.17 & 1.169 & -2.041 & 0.041 \\
\hline
\end{tabular}


pengetahuan berpikir positif pada subjek yang berada pada kelompok eksperimen. Untuk melihat perbandingan antara skor pretest-posttest tes pengetahuan berpikir positif (cek manipulasi) pada kelompok eksperimen, dapat dilihat pada grafik di bawah ini.

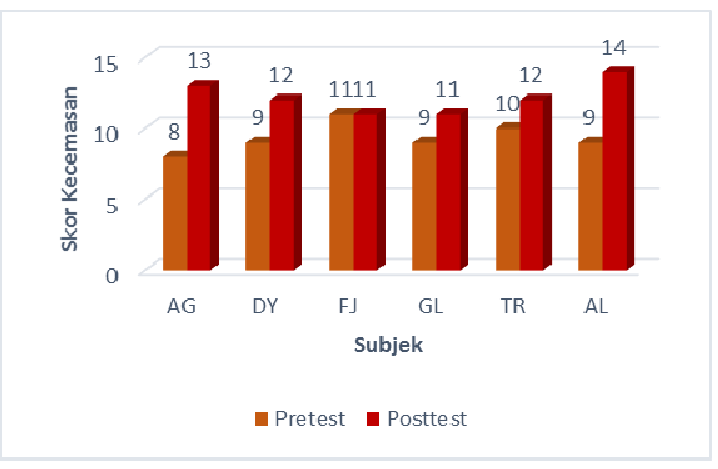

Gambar 1. Grafik pretest-posttest pengetahuan berpikir positif dalam cek manipulasi.

\section{Uji hipotesis}

Berdasarkan Tabel 1, pada baris time* ${ }^{*}$ roup diketahui bahwa $\mathrm{F}=93,699$ dan $\mathrm{p}=0,000 \quad(\mathrm{p}<0.05)$. Hal ini menunjukkan terdapat interaksi antara waktu (pretestposttest) dan kelompok (eksperimenkontrol). Interaksi ini menunjukkan bahwa perubahan skor pretest ke posttest kecemasan menghadapi masa bebas pada kedua kelompok (kontrol-eksperimen) berbeda secara signifikan. Selanjutnya adalah data selisih rerata kecemasan.
Tabel 2 menunjukkan bahwa perubahan skor kecemasan menghadapi masa bebas pada kelompok eksperimen adalah signifikan, dengan skor $\mathrm{MD}=11,333$ dan taraf signifikansi $0,000 \quad(p<0,05)$. Kelompok kontrol mengalami kenaikan rerata skor kecemasan, namun tidak mengalami perubahan yang signifikan, dengan skor $\mathrm{MD}=-0,500$ dan $\mathrm{p}=0,576$ $(\mathrm{p}<0,05)$. Hasil tersebut menunjukkan bahwa pelatihan berpikir positif dapat menurunkan kecemasan anak pada kelompok eksperimen dalam menghadapi masa bebas. Pada kelompok eksperimen, pelatihan berpikir positif memberikan sumbangan efektif terhadap penurunan kecemasan sebesar 0,945 atau $94,5 \%$.

Dari hasil analisis statistik, dapat disimpulkan bahwa pelatihan berpikir positif dapat menurunkan kecemasan menghadapi masa bebas pada para peserta pelatihan. Skor rata-rata kecemasan menghadapi masa bebas keseluruhan, antara pretest dan posttest mengalami penurunan skor sebanyak 11,3. Namun, jika dilihat skor kecemasan masing-masing individu, skor kecemasan setelah diberikan pelatihan tidak mengalami penurunan yang sama. Berikut gambaran grafik penurunan skor kecemasan pada masing-masing subjek.

Tabel 2.

Ringkasan uji hipotesis within subject effect pada kecemasan menghadapi masa bebas

\begin{tabular}{lccccc}
\hline \multicolumn{1}{c}{ Source } & $\begin{array}{c}\text { Type III Sum of } \\
\text { Squares }\end{array}$ & Df & Mean Square & F & Sig \\
\hline time & 176.042 & 1 & 176.042 & 78.532 & .000 \\
\hline $\begin{array}{l}\text { time* } \\
\text { group }\end{array}$ & 210.042 & 1 & 210.042 & 93.699 & .000 \\
\hline Error (time) & & & & & \\
\hline
\end{tabular}


Tabel 3.

Ringkasan tabel pairwise comparisons pada kecemasan menghadapi masa bebas

95\% Confidence Interval for

Difference

\begin{tabular}{lccccccc} 
Kelompok & Pretest & Posttest & $\begin{array}{c}\text { Mean } \\
\text { Difference } \\
\text { (Pre-post) }\end{array}$ & $\begin{array}{c}\text { Std } \\
\text { Error }\end{array}$ & Sig.* & Lower & Upper Bound \\
Bound & & \\
\hline Eksperimen & 1 & 2 & 11.333 & .864 & .000 & 9.407 & 13.259 \\
\hline Kontrol & 1 & 2 & -.500 & .864 & .576 & -2.426 & 1.426
\end{tabular}

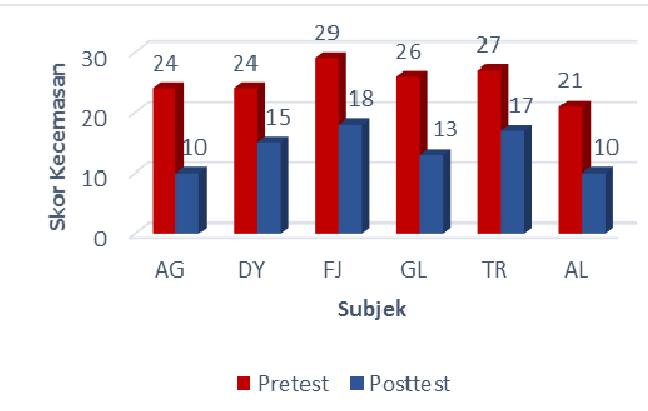

Gambar 2. Grafik Pretest-Posttest KecemasAn Menghadapi Masa Bebas Kelompok Eksperimen

\section{Diskusi}

Hasil analisis data menunjukkan bahwa pelatihan berpikir positif dapat menurunkan kecemasan menghadapi masa bebas pada anak di LPKA. Rerata empirik kecemasan menghadapi masa bebas sebelum diberikan intervensi berpikir positif sebesar 25,17, setelah diberikan intervensi turun menjadi 13,83. Rerata hipotetik skala kecemasan menghadapi masa bebas sebesar 18,5. Berdasarkan hal tersebut, dapat diketahui bahwa kondisi yang terjadi di lapangan benar ditemukan adanya kecemasan pada partisipan penelitian. Rerata skor kecemasan yang dimiliki para partisipan, berada di atas rata-rata berdasarkan alat ukur skala kecemasan. Kecemasan yang dialami para subjek dapat dikategorikan sedang hingga tinggi.

Hasil analisis juga menunjukkan, adanya perbedaan penurunan skor kecemasan menghadapi masa bebas yang signifikan, saat pretest ke posttest antara kelompok eksperimen yang mendapat perlakuan (pelatihan berpikir positif), dengan kelompok kontrol yang tidak mendapat perlakuan ( $\mathrm{F}=93,699 ; \mathrm{p}=0,000$ dengan nilai $\mathrm{p}<0,05)$. Skor kecemasan pada kelompok eksperimen, mengalami penurunan yang cukup besar dengan mean difference antara skor pretest dan posttest sebesar 11.333. Seluruh subjek dalam penelitian ini, mengaku dengan mengikuti pelatihan berpikir positif, dapat membantu wawasan dan kemampuan mereka, juga memberikan alternatif pola berpikir baru, untuk mengatasi kondisi saat kecemasan muncul. Sehingga bentuk intervensi kognitif seperti yang diberikan, dinilai dapat mengatasi permasalahan terkait dengan kecemasan.

Kecemasan yang berupa kegelisahan, ketakutan, dan kekhawatiran terhadap sesuatu yang akan terjadi, dan belum pasti, memunculkan adanya efek atau sensasi pada diri individu. Sensasi fisiologis seperti rasa berdebar, dan kesadaran akan adanya rasa takut, menjadi indikator bahwa seseorang 
merasakan kecemasan. Efek dari kecemasan juga memengaruhi cara berpikir dan persepsi. Kecemasan cenderung menghasilkan distorsi persepsi terutama pada makna dari sebuah peristiwa yang dialami. Distorsi ini yang kemudian dapat mengganggu proses belajar (Kaplan \& Saddock, 1997). Anak berkonflik dengan hukum yang akan menghadapi masa bebas, rentan terhadap perasaan inferioritas karena tekanan lingkungan sekitarnya dan umumnya akan dikucilkan serta dinilai negatif karena status mantan narapidana yang melekat. Hal yang kemudian berdampak pada kondisi psikologis anak. Anak merasakan kecemasan, perasaan curiga, depresi, frustasi, penyesalan yang sangat mendalam, dendam, marah, kehilangan kepercayaan kepada masyarakat, dan kehilangan kepercayaan diri (Abdillah, 2016).

Dengan memiliki persepsi dan penilaian yang positif terhadap masa bebas, anak juga akan memunculkan perasaan-perasaan yang juga lebih positif. Pelatihan berpikir positif, memberikan kesempatan kepada partisipan dalam penelitian ini, untuk dapat memunculkan dan mengembangkan kemampuan menilai kembali situasi atau kondisi yang memunculkan kecemasan pada diri mereka, dan menemukan alternatif pemikiran baru agar dapat lebih optimis memandang masa depan.

Pelatihan yang diberikan pada penelitian ini, berisi akan materi-materi atau psikoedukasi mengenai kecemasan, berpikir positif, serta keterkaitan antara pikiran, perasaan, dan perilaku. Pemberian materi-materi tersebut, bertujuan memberikan pemahaman dan tambahan informasi kepada subjek, khususnya pada materi kecemasan dan berpikir positif. Sebagai salah satu bentuk dari terapi kognitif, pelatihan berpikir positif membantu individu untuk dapat mengenali pola pikir negatif yang ada pada dirinya, memahami pola berpikir tersebut, dan kemudian mengubah pola berpikir yang negatif menjadi lebih positif. Harapan dari diberikannya pelatihan berpikir positif ini, individu mampu menggunakan pola pikir yang lebih positif untuk memunculkan keyakinan yang juga lebih optimis dalam menghadapi masa mendatang.

Pelatihan berpikir positif yang diberikan dengan pendekatan kelompok, dinilai baik digunakan dalam proses intervensi kognitif. Dimana dengan pendekatan kelompok, subjek diajak untuk berlatih berargumentasi dan berdiskusi dalam kelompok. Pendekatan kelompok, dianggap sangat membantu dalam membangun keterbukaan dan mempermudah proses pembelajaran pada masing-masing subjek. Subjek mampu memahami materi melalui diskusi, memberikan kesempatan untuk saling memberi dan menerima umpan balik, sehingga harga diri, keyakinan, pengertian, dan kepercayaan terhadap orang lain juga meningkat (Yalom, 2005).

Follow up, diskusi, dan wawancara lanjutan, dilakukan pada subjek di kelompok eksperimen 2 minggu setelah pelaksanaan pelatihan berpikir positif. Hal ini bertujuan untuk melihat efek pelatihan dan membahas perubahanperubahan yang dialami partisipan, serta bagaimana kesiapan untuk menghadapi masa bebas, baik secara kognitif, emosi, maupun fisiologis. Berdasarkan hasil pengukuran dengan skala kecemasan kembali, skor kecemasan partisipan secara keseluruhan tidak mengalami peningkatan, cenderung tetap dan menurun. Hasil wawancara dan diskusi yang diperoleh, juga menunjukkan perubahan dalam hal kognitif, fisiologis, dan emosi yang sudah jauh lebih membaik, dengan tidak begitu sulit tidur lagi, gelisah yang berkurang, rasa pusing 
dan kelelahan juga sudah jarang muncul. Hasil follow up, diskusi, dan wawancara lanjutan memperlihatkan jika pengetahuan yang didapat selama proses pelatihan masih dapat digunakan dengan cukup baik oleh para peserta. Hal ini kemudian menjadikan berpikir positif tidak hanya mampu menurunkan kecemasan, namun dapat dikembangkan sebagai sebuah kemampuan untuk dapat mengelola kecemasan itu sendiri. Kecemasan yang dirasakan tidak kemudian menjadi hilang sepenuhnya, namun tingkatan dari kecemasan itu sendiri yang mengalami penurunan. Dengan mengembangkan dan mempertahankan kemampuan berpikir positif yang sudah ada, diharapkan dapat menjadi alternatif dalam mengelola kecemasan saat muncul kembali.

\section{Kesimpulan}

Berdasarkan hasil analisis dan pembahasan dalam penelitian ini, maka dapat disimpulkan bahwa pemberian pelatihan berpikir positif mampu menurunkan kecemasan menghadapi masa bebas pada anak di Lembaga Pembinaan Khusus Anak. Skor kecemasan terus menurun setelah pemberian pelatihan berpikir positif, dan terdapat perubahan pada aspek kognitif, emosi, fisiologis serta perilaku pada keenam subjek. Hasil analisis menunjukkan adanya perbedaan yang signifikan pada penurunan skor kecemasan menghadapi masa bebas dari pretest menuju posttest bahkan setelah dilakukan follow up kepada kelompok eksperimen.

\section{Saran}

Peneliti selanjutnya disarankan dapat melakukan penelitian dengan konsep ini terhadap kelompok subjek yang berbeda (misalnya kepada anak didik di LPKA yang berjenis kelamin wanita, maupun warga binaan di Lembaga Pemasyarakatan). Kajian ini nantinya akan menambah wawasan mengenai adanya faktor-faktor lain yang menimbulkan kecemasan menghadapi masa bebas, terutama jika dilakukan pada subjek wanita atau subjek dengan rentan usia yang berbeda, yang juga akan mendekati masa bebas. Pada proses pelaksanaan pelatihan, disarankan jika memungkinkan untuk memberikan tugas rumah sebagai media berlatih di luar proses pelaksanaan pelatihan. Hal ini dikarenakan, dengan adanya pemberian tugas rumah, partisipan dapat belajar mengingat dan berlatih kembali apa yang sudah didapatkan dari pelatihan.

Praktisi pada bidang psikologi klinis dan sosial, disarankan juga untuk dapat menggunakan pelatihan berpikir positif sebagai salah satu alternatif intervensi untuk menurunkan kecemasan menghadapi masa bebas. Praktisi juga diharapkan dapat mengembangkan model penelitian ini, dalam menyusun rancangan pendekatan dan pelaksanaan intervensi-intervensi psikologis. Hal demikian diharapkan dapat menjadi salah satu upaya pengembangan bentuk intervensi terkait kecemasan menghadapi masa bebas.

Bentuk kegiatan pelatihan seperti yang dilakukan dalam penelitian ini, penting untuk tetap dilanjutkan kedepannya di LPKA, terlebih terkait kondisi psikologis anak. Hal ini dikarenakan, pentingnya pendampingan yang dapat membantu anak mengenali dan menyelesaikan masalah psikologis yang dialaminya. Melalui kegiatan seperti pelatihan ini, anak diberikan kesempatan untuk dapat belajar mengungkapkan apa yang dirasakannya, dan mendapatkan pengetahuan baru dalam mengatasi permasalahan psikologis yang dialaminya. 


\section{Kepustakaan}

Abdillah, R. (2016). Dinamika psikologis anak yang berhadapan dengan hukum. Buletin Konsorsium Psikologi Ilmiah Nusantara, 2(6), 78.

Caprara, G. V. \& Steca, P. (2006). The contribution of self-regulatory efficacy beliefs in managing affect and family relationships to positive thinking and hedonic balance. Journal of Clinical and Social Psychology, 25(6), 603-627. doi: $10.1521 / 2006.25 .6 .603$.

Chaplin, J. P. (2011). Kamus lengkap psikologi. Jakarta: PT. Raja Grafindo Persada.

Cook, T. D. \& Campbell, D. T. (1979). Quasi-experimentation: Design $\mathcal{E}$ analysis issues for field setting. Boston: Houghton Miffin Company.

Elfiky, I. (2009). Terapi berpikir positif. Jakarta: Zaman.

Febrilinda, L. (2016). Gambaran kecemasan menjelang bebas pada anak di lembaga pembinaan khusus anak klas IIB tanjung pati (Skripsi tidak terpublikasi). Padang: Fakultas Kedokteran Universitas Andalas.

Halgin, R. P. \& Whitbourne, S. K. (2010). Abnormal psychology. Clinical perspective on psychology disorders (6 $6^{\text {th }}$ ed.). Boston: McGraw-Hill Higher Education.

Hardiani, C. A. (2012). Kecemasan dalam menghadapi masa bebas pada narapidana anak di Lembaga Pemasyarakatan Anak Kutoarjo (Skripsi tidak terpublikasi). Yogyakarta: Fakultas Ilmu Pendidikan Universitas Negeri Yogyakarta.

Kaplan, H. I., Sadock, B. J. \& Grebb, J. A. (1997). Sinopsis psikiatri: Ilmu pengetahuan perilaku psikiatri klinis (jilid 2). (W. Kusuma, Terjemahan) Jakarta: Binarupa Aksara.

Lewis, S. P. (1997). Test anxiety. DRC Learning Specialist, 100, 204-232.

Mertler, C. A. (2006). Action research: Teacher as researchers in the classroom. London: Sage Publication, Inc.

Peale, N. V. (1996). Berpikir positif. Jakarta: Binarupa Aksara.

Seligman, M. E. P. (2006). Learned optimism how to change your mind and your life. New York: Alfred A. Knof Publisher.

Shadish, W. R., Cook, T. D., \& Campbell, D. T. (2002). Experimental and quasi-experimental designs for generalized causal inference. Boston: Houghton, Mifflin and Company.

Stallard, P. (2005). A clinician's guide to think good - feel good: Using CBT with children and young people. West Sussex: John Wiley \& Sons.

Spielberger, C. D. (1972). Anxiety current trends in theory and research. London: Academic Press.

Wadsworth, M. E., Gudmundsen, G. R., Raviv, T., Ahlkvist, J. A., Mclntosh, D. N., Kline, G. H. et al. (2004). Coping with terrorism: Age and gender differences in effortful and involuntary responses to september $11^{\text {th }}$. Journal of Applied and Developmental Science, 8(3), 143-157. doi: 10.1207/s1532480 xads08034.

Zeidner, M. \& Matthews G. (2010). Anxiety 101. The psych 101 series ( $1^{\text {st }}$ ed.). New York: Springer Publishing Company.

Yalom, I. D., \& Leszcz, M. (Collaborator). (2005). The theory and practice of group psychotherapy (5 ${ }^{\text {th }}$ ed.). New York: Basic Books. 